\title{
New anthropochore millipedes in the faunas of Asian Russia, Kazakhstan and Kyrgyzstan (Diplopoda)
}

\section{Новые антропохорные двупарноногие многоножки в фаунах азиатской России, Казахстана и Кыргызстана (Diplopoda)}

\author{
P.S. Nefediev ${ }^{1,2}$, J.S. Nefedieva ${ }^{3}$ \\ П.С. Нефедьев ${ }^{1,2}$, Ю.С. Нефедьева
}

\footnotetext{
${ }^{1}$ Altai State University, Lenin Avenue, 61, Barnaul 656049 Russia. E-mail: p.nefediev@mail.ru

${ }^{2}$ Tomsk State University, Biological Institute, Lenin Avenue, 36, Tomsk 634050 Russia.

${ }^{3}$ Germes Ltd., Papanintsev Street, 105, Barnaul 656049 Russia. E-mail: j.nefedieva@mail.ru

${ }^{1}$ Алтайский государственный университет, проспект Ленина, 61, Барнаул 656049 Россия.

2 Томский государственный университет, Биологический институт, проспект Ленина, 36, Томск 634050 Россия.

${ }^{3}$ ООО «Гермес», ул. Папанинцев, 105, Барнаул 656049 Россия.
}

KEY WORDS: Nopoiulus kochii, Cylindroiulus caeruleocinctus, Polydesmus denticulatus, Polydesmus inconstans, anthropochore, introduction, new records, Altai Province, Novosibirsk Area, Finland.

КЛЮЧЕВЫЕ СЛОВА: Nopoiulus kochii, Cylindroiulus caeruleocinctus, Polydesmus denticulatus, Polydesmus inconstans, антропохор, интродукция, новые находки, Алтайский край, Новосибирская область, Финляндия.

ABSTRACT. New faunistic records of anthropochore millipedes supplement the regional lists of Diplopoda of the Novosibirsk Area and the Altai Province, both southwestern Siberia, Russia, as well as of eastern Kazakhstan and Kyrgyzstan. Distribution data and remarks are provided for all encountered species.

How to cite this article: Nefediev P.S., Nefedieva J.S. 2018. New anthropochore millipedes in the faunas of Asian Russia, Kazakhstan and Kyrgyzstan (Diplopoda) // Arthropoda Selecta. Vol.27. No.2. P.107-110. doi: 10.15298/arthsel. 27.2.01

PЕЗЮМЕ. Региональные списки видов Diplopoda для Новосибирской области и Алтайского края (юг Западной Сибири, Россия), а также для Восточного Казахстана и Кыргызстана пополнены новыми фаунистическими находками антропохорных двупарноногих многоножек. Для всех видов приводятся сведения по их распространению и замечания.

\section{Introduction}

During the last few years, at least 10 species from 7 genera, 5 families and two orders of Diplopoda have been recorded as anthropochore introductions from Asian Russia [Nefediev et al., 2013, 2014a, b, 2016], but our knowledge of that fauna in the Asian part of Russia is still far from complete. Moreover, the anthropochore millipede faunas of Kazakhstan and Kyrgyzstan remain barely explored [Nefediev et al., 2014b].

The material treated below has mainly been deposited in the collection of the Altai State University,
Barnaul, Russia (ASU), partly shared also with the collections of the Zoological Museum of the Lomonosov Moscow State University, Moscow, Russia (ZMUM) and the Federal Scientific Center of East Asian Terrestrial Biodiversity, Far Eastern Branch, Russian Academy of Sciences, Vladivostok, Russia (FSCB), as indicated in the text. SEM micrographs were prepared at the Laboratory of Aquatic Ecology, Institute for Water and Environmental Problems, Siberian Branch, Russian Academy of Sciences, Barnaul, Russia using a Hitachi S-3400N scanning electron microscope. Literature references to the species concern Asian Russia only.

Taxonomic part

\section{Class Diplopoda}

Order Julida

Family BLANIULIDAE

Nopoiulus kochii (Gervais, 1847)

Nopoiulus kochii — Lokšina, Golovatch, 1979: 385; Golovatch, Enghoff, 1990: 115; Mikhaljova, 1993: 9; 1998a: 6; 1998b: 73, 74: figs; 2009a: 2; 2009b: 601; 2012: 112; 2017: 123, 124: figs, 136: map; Mikhaljova, Nefediev, 2003: 85; Nefediev, Nefedieva, 2006: 98; 2011: 100; Nefediev et al., 2014a: 64; 2014b: 341, map.

MATERIAL EXAMINED. $3 \sigma^{\top} \sigma^{\top}, 2$ 우, 6 juv. (ASU), Russia, southwestern Siberia, Altai Province, Kalmanka District, near Zimari, "Prudskoe" Gardening Partnership, on tomatoes, 30.08.2015, leg. V.Yu. Petrov; $80^{7} \sigma^{7}, 13$ OQ, 1 juv. (ASU), same Province, Barnaul, Shukshin Street, 53.372176 ${ }^{\circ}$, 83.66932 $8^{\circ}$ E, Betula pen- 

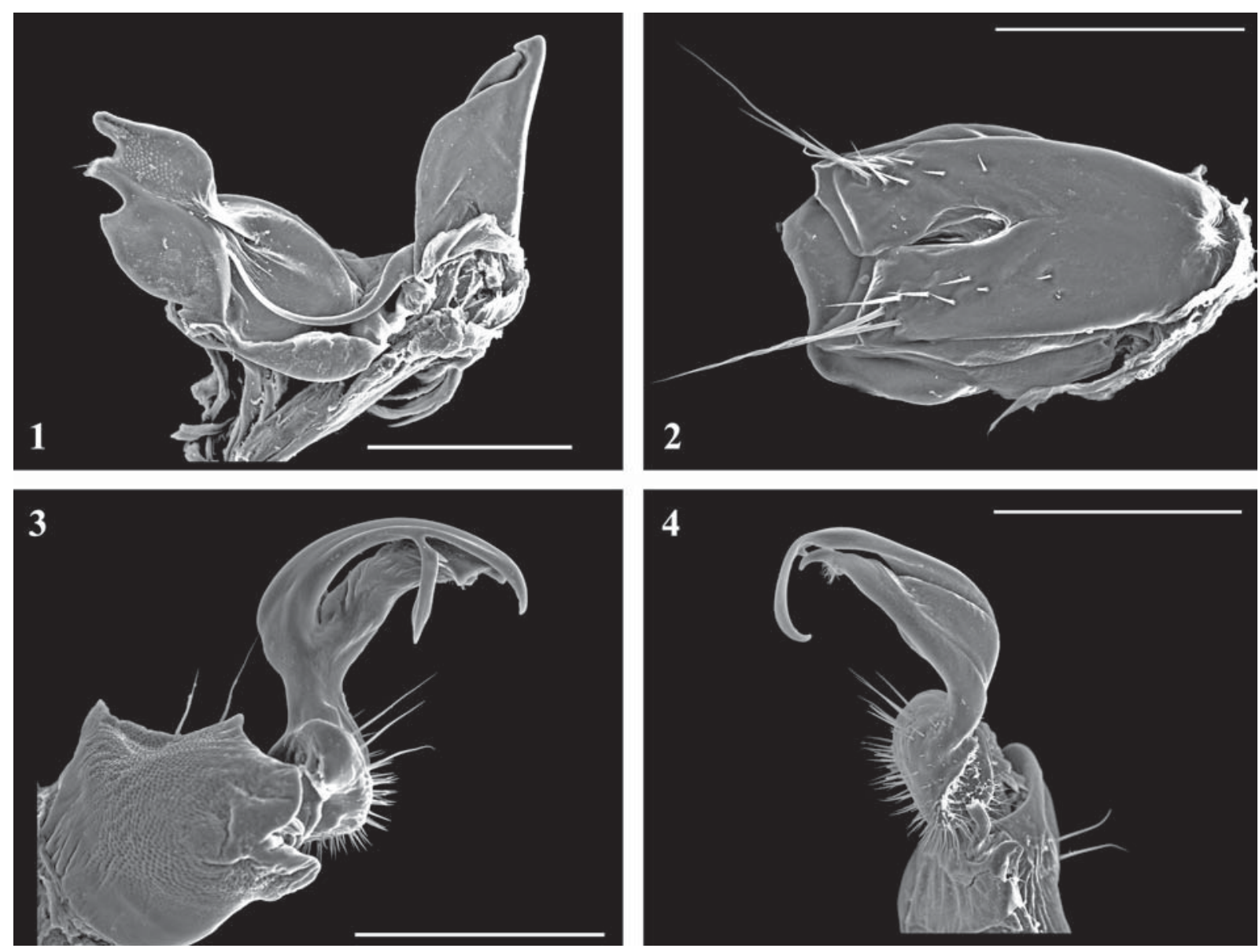

Figs 1-4. Cylindroiulus caeruleocinctus (Wood, 1864). 1 - gonopods, mesal view; 2 - vulva, caudal view; Polydesmus denticulatus C.L. Koch, 1847. 3 - gonopods, lateral view; Polydesmus inconstans Latzel, 1884. 4 - gonopods, mesal view. Scale bar: 0.5 (1, 4), 0.4 (3) and $0.3 \mathrm{~mm}(2)$.

Рис. 1-4. Cylindroiulus caeruleocinctus (Wood, 1864). 1 - гоноподы, вид изнутри; 2 - вульва, вид сзади; Роlydesmus denticulatus C.L. Koch, 1847. 3 - гоноподы, вид сбоку; Polydesmus inconstans Latzel, 1884. 4 - гоноподы, вид изнутри. Масштаб: $0,5(1,4), 0,4$ (3) и 0,3 мм (2).

dula and Acer stand, above cellars, 11.04.2016, leg. P.S. Nefediev; $1 \mathrm{O}^{7}, 1$ ㅇ, 1 juv. (ASU), same Province, Biysk, Centre of Hygiene and Epidemiology of the Altai Province, $52.536175^{\circ} \mathrm{N}$ $85.212581^{\circ} \mathrm{E}$, Betula pendula stand, 15.08.2016, leg. P.S. Nefediev, J.S. Nefedieva; $9 \sigma^{7} \sigma^{7}, 10$ 우, 6 juv., 1 fragm. (ASU), same Province, Barnaul, $53.273251^{\circ} \mathrm{N}, 83.753012^{\circ} \mathrm{E}$, August 2017 , leg A.G. Inozemtsev; $30^{7} \sigma^{\top}, 11$ oO, 3 juv., 1 fragm. (ASU), same Province, Barnaul, near Altai Province Sport School, $53.355274^{\circ} \mathrm{N}$, $83.727085^{\circ} \mathrm{E}$, Ulmus and Betula pendula stand, above cellars, 3.11.2017, leg. P.S. Nefediev; $1 \sigma^{7}, 2$ oᄋ (ASU), Kazakhstan, Pavlodar Area, Ekibastuz, kitchen-garden, 1-2.05.2016, leg. I.S. Koroleva; 1 , 1 juv. (ASU), Kyrgyzstan, Chui Area, 65 km SE Bishkek, Ysyk-Ata, 22.07.2015; 3 O0, 6 juv. (ASU), same Area, 20 km N Bishkek, Ala-Too Sovkhoz, garden, 30.07.2015, all leg. Yu.V. Dyachkov.

DISTRIBUTION. This ubiquitous species is widespread all over the world through human agency [Nefediev et al., 2014b].

REMARKS. This species has hitherto been recorded from neither eastern Kazakhstan nor Kyrgyzstan, these records are being related to anthropogenic activity. Both the genus Nopoiulus Menge, 1851 and the family Blaniulidae, where $N$. kochii belongs, are formally new to the millipede fauna of Kyrgyzstan.

\section{Family JULIDAE}

Brachyiulus jawlowskii Lohmander, 1928

Brachyiulus jawlowskii - Nefediev et al., 2014a: 64; 2014b: 344; Mikhaljova, 2017: 58, 59: fig, 90: map.

MATERIAL EXAMINED. 4 OP (ASU), Russia, southwestern Siberia, Altai Province, Barnaul, Shukshin Street, $53.372176^{\circ} \mathrm{N}$, $83.669328^{\circ} \mathrm{E}$, Betula pendula and Acer stand, above cellars, 11.04 .

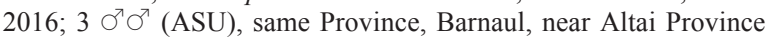
Sport School, $53.355274^{\circ} \mathrm{N}, 83.727085^{\circ} \mathrm{E}$, Ulmus and Betula pendula stand, above cellars, 3.11.2017, all leg. P.S. Nefediev.

DISTRIBUTION AND REMARKS. This species is mainly known from European Russia and adjacent European countries, also introduced through human agency to western Kazakhstan and the Altai Province, SW Siberia, Asian Russia [Nefediev et al., 2014b].

\section{Cylindroiulus britannicus (Verhoeff, 1891)}

Cylindroiulus latestriatus - Mikhaljova, Nefediev, 2003: 85; Nefediev, Nefedieva, 2006: 98; 2011: 100

Cylindroiulus britannicus - Nefediev et al., 2013: 340, map; 2014a: 64; 2014b: 342, map; Mikhaljova, 2017: 55, 56: figs, map. 
MATERIAL EXAMINED. $1 \sigma^{7}$ (ASU), Russia, southwestern Siberia, Altai Province, Barnaul, near Altai Province Sport School, $53.355274^{\circ} \mathrm{N}, 83.727085^{\circ} \mathrm{E}$, Ulmus and Betula pendula stand, above cellars, 3.11.2017, leg. P.S. Nefediev.

DISTRIBUTION AND REMARKS. This species is mainly associated with human activity and widespread throughout Europe, also introduced to the SW part of Asian Russia, India, Australia, New Zealand, the USA, Canada, South Africa and South America. In Asian Russia, this species inhabits anthropogenic and semi-natural habitats like city parks in the Tomsk Area and the Altai Province [Nefediev et al., 2014b].

\section{Cylindroiulus caeruleocinctus (Wood, 1864)} Figs 1-2.

MATERIAL EXAMINED. $1 \sigma^{7}$ (ZMUM $\left.\rho 3747\right), 1 \sigma^{7}$ (FSCB), $9 \sigma^{7} \sigma^{7}, 2$ 우 (ASU), Finland, Turku, on wall of a building, end of October 2015, leg. A.A. Fomichev.

DISTRIBUTION. This is a Cylindroiulus species very widespread across Europe, ranging from Great Britain and Ireland in the west and Scandinavia in the north, through central European countries to the northern parts of Spain, Portugal and Italy in the south, and the Baltic states, the western parts of Russia, Ukraine and Slovakia in the east; also introduced to Canada and the eastern coast of the USA. The only previously known record of this species from Finland concerned Helsinki and dated back to 1933 [Andersson et al., 2005].

REMARKS. The above record of $C$. caeruleocinctus from Finland is only the second locality of the species in the country.

\section{Order Polydesmida}

\section{Family POLYDESMIDAE}

\section{Polydesmus denticulatus C.L. Koch, 1847} Fig. 3.

Polydesmus denticulatus - Mikhaljova, Nefediev, 2003: 83; Mikhaljova, 2004: 222, figs, 107: map; 2017: 270, figs, 92: map; Nefediev, Nefedieva, 2008: 118; 2011: 100; Nefediev et al., 2014a: 64; 2014b: 339, map; Bukhkalo et al., 2014: 74.

MATERIAL EXAMINED. 1 (ASU), Russia, southwestern Siberia, Altai Province, Barnaul, Yubileinyi Park, soil sample (0$10 \mathrm{~cm}$ deep), July 2014, leg. A.A. Streltsova; $1 \sigma^{7}, 1$ q (ZMUM

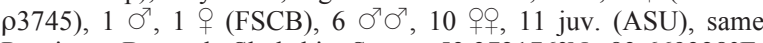
Province, Barnaul, Shukshin Street, 53.372176 ${ }^{\circ} \mathrm{N}, 83.669328^{\circ} \mathrm{E}$ Betula pendula and Acer stand, above cellars, 11.04.2016; $7 \bigcirc^{7} \sigma^{7}$, 1 , 11 juv. (ASU), same Province, Barnaul, near Altai Province Sport School, $53.355274^{\circ} \mathrm{N}, 83.727085^{\circ} \mathrm{E}$, Ulmus and Betula pendula stand, above cellars, 3.11.2017, all leg. P.S. Nefediev.

DISTRIBUTION. This species is widespread throughout Europe, also introduced to Canada. In Asian Russia, it has previously been reported from anthropogenic and seminatural habitats in the cities of Tomsk and Tobolsk, Tomsk and Tyumen areas, respectively [Mikhaljova, Nefediev, 2003. Nefediev, Nefedieva, 2011; Bukhkalo et al., 2014; Nefediev et al., 2014b].

REMARK. This is the first record of $P$. denticulatus in the Altai Province, SW Siberia, Asian Russia.

\section{Polydesmus inconstans Latzel, 1884}

Fig. 4.

Polydesmus inconstans - Nefediev et al., 2016: 19, 20: fig; Mikhaljova, 2017: 271, fig, 292: map.
MATERIAL EXAMINED. $1 \sigma^{\text {r, }} 3$ juv. (ASU), Russia, southwestern Siberia, Novosibirsk Area, Novosibirsk District, valley of Inya River, right bank, "Izumrud" Gardening Partnership, $55^{\circ} 00^{\prime}$ $13^{\prime \prime} \mathrm{N}, 83^{\circ} 21^{\prime} 30^{\prime \prime} \mathrm{E}$, open hand-made ground, $110 \mathrm{~m}$ a.s.1., 23.07.

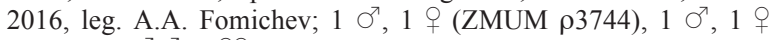
(FSCB), $2 \sigma^{7} \sigma^{7}, 5$ 90,3 juv. (ASU), Kazakhstan, East Kazakhstan Area, Zyryanovsk, garden, ca. $500 \mathrm{~m}$ a.s.1., 24.06.2016; $1 \sigma^{\top}, 1$ ㅇ (ZMUM $\rho 3746), 2$ ○ $\sigma^{7}, 1$, 23 juv. (ASU), Kyrgyzstan, $20 \mathrm{~km} \mathrm{~N}$ Bishkek, Ala-Too Sovkhoz, garden, 30.07.2015, all leg. Yu.V. Dyachkov.

DISTRIBUTION. This species is very widespread throughout Europe, ranging from Scandinavia and Iceland in the north to mainland Spain and Italy in the south, and to the Republic of Bashkortostan in the east of European Russia; also introduced to the USA, Canada and New Zealand. In the Asian part of Russia, this species has previously been known from a single anthropogenic locality in the Altai Province [Nefediev et al., 2016].

REMARKS. The above records of $P$. inconstans from the Novosibirsk Area, southwestern Siberia, Russia, and both eastern Kazakhstan and northern Kyrgyzstan are new to the regional millipede lists.

\section{Conclusions}

The following records of anthropochore millipedes are new to the millipede faunas of certain countries or areas: both the genus Nopoiulus Menge, 1851 and $N$. kochii (Gervais, 1847), as well as the family Blaniulidae they belong to, to Kyrgyzstan; Polydesmus denticulatus C.L. Koch, 1847 to the Altai Province, SW Siberia, Asian Russia; Polydesmus inconstans Latzel, 1884 to the Novosibirsk Area, SW Siberia, Asian Russia and also to both eastern Kazakhstan and Kyrgyzstan.

ACKNOWLEDGEMENTS. We are most thankful to S.I. Golovatch (Moscow, Russia) who kindly checked the English of an advanced draft. Our deepest gratitude is extended to all collectors who donated us material for the present study. We are very much obliged to V.V. Kirillov who kindly provided the facilities to take SEM micrographs and to A.V. Dyachenko for the assistance in using the SEM facilities at the Laboratory of Aquatic Ecology, Institute for Water and Environmental Problems, Siberian Branch of the Russian Academy of Sciences, Barnaul, Russia.

\section{References}

Andersson G., Meidell B.A., Scheller U., Winqvist, J.-Å., Osterkamp Madsen M., Djursvoll P., Budd G., Gärdenfors U. 2005. Nationalnyckeln till Sveriges flora och fauna. Mångfotingar. Myriapoda. Uppsala: ArtDatabanken, SLU. 351 p.

Bukhkalo S.P., Galitch D.E., Sergeeva E.V., Vazhenina N.V. 2014. [Synopsis of the invertebrate fauna of the southern taiga in western Siberia (the Lower Irtysh basin)]. Moscow: KMK Scientific Press. 189 p. [in Russian].

Golovatch S.I., Enghoff H. 1990. [The millipede Nopoiulus kochii (Gervais, 1847) in the Caucasus (Diplopoda, Julida, Blaniulidae)] // Striganova B.R. (ed.). Fauna nazemnykh bespozvonochnykh Kavkaza. Moscow: Nauka Publ. P.114-118 [in Russian].

Lokšina I.E., Golovatch S.I. 1979. Diplopoda of the USSR fauna // Pedobiologia. Vol.19. No.6. P.381-389. 
Mikhaljova E.V. 1993. The millipedes (Diplopoda) of Siberia and the Far East of Russia // Arthropoda Selecta. Vol.2. No.2. P.336.

Mikhaljova E.V. 1998a. On new and poorly-known millipedes (Diplopoda) from the Far East of Russia // Far Eastern Entomologist. No.60. P.1-8.

Mikhaljova E.V. 1998b. The millipedes of the Far East of Russia (Diplopoda) // Arthropoda Selecta. Vol.7. No.1. P.1-77.

Mikhaljova E.V. 2004. The millipedes (Diplopoda) of the Asian part of Russia. Sofia-Moscow: Pensoft Publ. 292 p.

Mikhaljova E.V. 2009a. A list of the millipedes (Diplopoda) of the Russian Far East // Far Eastern Entomologist. No.197. P.1-8.

Mikhaljova E.V. 2009b. The millipede (Diplopoda) of the Russian Far East islands and the Kamchatka Peninsula // Soil Organisms. Vol.81. No.3. P.599-616.

Mikhaljova E.V. 2012. [Millipede (Diplopoda) taxonomic diversity in the Asian part of Russia] // Konferentsiya s mezhdunarodnym uchastiem "Regiony novogo osvoeniya: teoreticheskie prakticheskie voprosy izucheniya i sokhraneniya biologicheskogo i landshaftnogo raznoobraziya", 15-18 okt. 2012 Khabarovsk: sbornik dokladov. Khabarovsk: Institute for Water and Environmental Problems, Far Eastern Branch, Russian Academy of Sciences Publ. P.111-114 [in Russian, summary in English].

Mikhaljova E.V. 2017. [The millipede fauna (Diplopoda) of the Asian part of Russia]. Vladivostok: Dalnauka Publ. 336 p. [in Russian, with English summary].

Mikhaljova E.V., Nefediev P.S. 2003. A contribution to the millipede fauna of Siberia (Diplopoda) // Arthropoda Selecta. Vol.11. No.1. P.81-87 (for 2002).

Nefediev P.S., Kocourek P., Nefedieva J.S. 2016. The first record of Polydesmus inconstans Latzel, 1884 (Diplopoda: Polydesmida: Polydesmidae) in the Asian part of Russia // Arthropoda Selecta. Vol.25. No.1. P.19-21.

Nefediev P.S., Nefedieva J.S. 2006. [Regional peculiarities of millipede fauna (Diplopoda) in the southeast of Western Siberia] //
Materialy X Mezhdunarodnoy shkoly-konferentsii studentov i molodykh uchenykh "Ekologiya Yuzhnoi Sibiri i sopredelnykh territoriy". Abakan: Khakassian State University Publ. Vol.10. No.1. P.98 [in Russian].

Nefediev P.S., Nefedieva J.S. 2008. [A historical review of faunistic investigations of millipedes (Diplopoda) in Western Siberia] // Vazhov V.M. (ed.). Altai: ekologiya i prirodopolzovanie. Trudy VII rossiisko-mongolskoy nauchnoy konferentsii molodykh uchyonykh i studentov. Vol.1. Biysk: Biysk Pedagogical State University Publ. P.117-120 [in Russian].

Nefediev P.S., Nefedieva J.S. 2011. [Millipedes (Diplopoda) of the green plantations of Tomsk City and its suburbs] // Romanenko V.N. (ed.). Kontseptualnye i prikladnye aspekty nauchnukh issledovaniy v oblasti zoologii bespozvonochnykh. Sbornik materialov III Vserossiyskoi shkoly-seminara s mezhdunarodnym uchastiem, posvyaschennoi 120-letiyu so dnya rozhdeniya Rostislava Petrovicha Berezhkova (1891-1961), Tomsk, 2427 okt. 2011. Tomsk: Agraf-Press Publ. P.100-102 [in Russian].

Nefediev P.S., Nefedieva J.S., Dyachkov Yu.V. 2013. Review of the millipede genus Cylindroiulus Verhoeff, 1894 in the Asian part of Russia (Diplopoda: Julida: Julidae) // Arthropoda Selecta. Vol.22. No.4. P.339-342.

Nefediev P.S., Nefedieva J.S., Dyachkov Yu.V. 2014a. A review of the anthropochore fauna of Asian Russia, with new records from the Altai Province, Siberia (Diplopoda) // Tuf I.H., Tajovský K. (eds.). 16th International Congress of Myriapodology. Book of Abstracts. Olomouc: Institute of Soil Biology, BC ASCR \& Faculty of Science, Palacký University. P.64.

Nefediev P.S., Nefedieva J.S., Dyachkov Yu.V. 2014b. A review of the anthropochore millipede fauna of Asian Russia, with new records from the Altai Province, Siberia (Diplopoda) // Arthropoda Selecta. Vol.23. No.4. P.337-345.

Responsible editor S.I. Golovatch 